\title{
Correction: S1PR1 drives a feedforward signalling loop to regulate BATF3 and the transcriptional programme of Hodgkin lymphoma cells
}

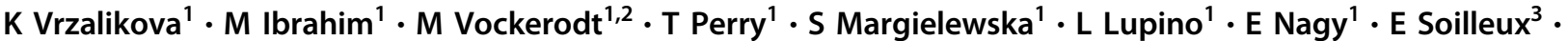 \\ D Liebelt ${ }^{1} \cdot$ R Hollows $^{1} \cdot$ A Last $^{1} \cdot$ G Reynolds $^{4} \cdot M$ Abdullah $^{1,5} \cdot$ H Curley $^{1} \cdot M$ Care $^{6} \cdot$ D Krappmann $^{7} \cdot$ R Tooze $^{6} \cdot$ \\ J Allegood ${ }^{8} \cdot$ S Spiegel ${ }^{8} \cdot$ W Wei $^{1,9} \cdot$ C B J Woodman ${ }^{1} \cdot$ P G Murray ${ }^{1,10}$
}

Published online: 25 June 2019

(c) The Author(s) 2019. This article is published with open access

\section{Correction to: Leukemia}

https://doi.org/10.1038/leu.2017.275

This article was originally published under a CC BY-NCND 4.0 license, but has now been made available under a CC-BY 4.0 license.

P G Murray

p.g.murray@bham.ac.uk

1 Institute of Cancer and Genomic Sciences, University of Birmingham, Birmingham, UK

2 Institute of Anatomy and Cell Biology, Georg-August University of Göttingen, Göttingen, Germany

3 Department of Cellular Pathology, John Radcliffe Hospital, Oxford, UK

4 Institute of Immunology and Immunotherapy, University of Birmingham, Birmingham, UK

5 Department of Pathology, Universiti Putra Malaysia, Selangor, Malaysia
Open Access This article is licensed under a Creative Commons Attribution 4.0 International License, which permits use, sharing, adaptation, distribution and reproduction in any medium or format, as long as you give appropriate credit to the original author(s) and the source, provide a link to the Creative Commons license, and indicate if changes were made. The images or other third party material in this article are included in the article's Creative Commons license, unless indicated otherwise in a credit line to the material. If material is not included in the article's Creative Commons license and your intended use is not permitted by statutory regulation or exceeds the permitted use, you will need to obtain permission directly from the copyright holder. To view a copy of this license, visit http://creativecommons. org/licenses/by/4.0/.
6 Leeds Institute of Cancer and Pathology, University of Leeds, Leeds, UK

7 Research Unit Cellular Signal Integration, Helmholtz Zentrum München, Neuherberg, Germany

8 Department of Biochemistry and Molecular Biology and Massey Cancer Center, Virginia Commonwealth University School of Medicine, Richmond, VA, USA

9 Sheffield Institute of Translational Neuroscience, University of Sheffield, Sheffield, UK

10 Department of Clinical and Molecular Pathology, Institute of Molecular and Translational Medicine, Faculty of Medicine and Dentistry, Palacky University, Olomouc, Czech Republic 